\title{
Potential \& Current Status of Solar Energy in Pakistan Policy, Planning \& Strategy
}

\author{
Sobab Khan ${ }^{1}$, Mudasar Rashid ${ }^{2}$, Muhammad Aitezaz Husain ${ }^{3}$, Ahtasham Rahim ${ }^{4}$, Sami Ullah Shah ${ }^{5}$ \\ 1,2,3,4,5 Center.For.Advanced.Studies.In.Energy University of Engineering and Tecnology, Peshawar 25000, Pakistan

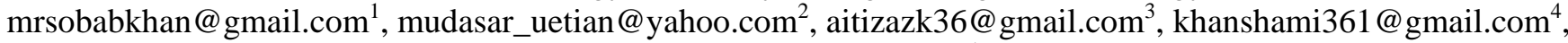 \\ samishah93@hotmail.com ${ }^{5}$ \\ Received: 04 February, Revised: 13 February, Accepted: 15 February
}

\begin{abstract}
When we study about, analyze \& understand the basic needs of human beings, we come to know that energy is the most primitive need of human being. The developed countries of Asia, Europe Africa \& Australia, the standard of life of the inhabitants is high because of per capita consumption of these countries is high. In short status of energy in a country defines the high standard of living within a country. When we analyze the energy condition of Pakistan, we come to know that, Pakistan right now is facing a huge energy crisis, lowering down the economy of the country. This is because of the dependency of power plants on conventional sources of energy such as coal, diesel \& other thermal resources, lack of proper policy making $\&$ the implementation of existing policy. The study I carried out will point out the problems related to policies \& problems within the departments that hider the development of energy power plants for non-conventional \& renewable energy sources. We'll find out, how to get rid of the problems we face regarding the development of renewable energy projects in general \& solar energy projects in particular in policy prospective. We need to know that despite of huge potential of energy why are we lacking behind? What are the steps forward to counter the problems? I will try to sort out the problem keeping policy prospective in mind particularly of solar energy. Many of the developed countries in Europe, Australia \& Asia utilize energy from the sun for the generation of electrical \& thermal energy, have developed solar energy policies. United States, China \& Germany are the most successful countries, generating most of the energy from solar \& wind power. The reason behind the successful utilization of energy from the sun by these countries is because of their up-to-date policies, planning \& strategies. These policies, planning \& strategies includes immunity from tax, subsidizations of the projects, convincible bills \& tariff, \& provision of incentives \& many more profit oriented steps that had been defined in the literature below. The renewable energy policies in general \& solar energy policies in particular implemented by the above mentioned countries provide us with huge amount of motivations \& tactics to develop a framework to develop solar energy projects, both of solar thermal \& photovoltaic in the urban as well as in the rural areas of the country. Moreover the framework for off grid \& on grid system, rooftop system, onshore \& offshore systems presented by these
\end{abstract}

developed countries can also be followed if comparable to the conditions of our country. This research proposal is a step towards the finding the potential, current status \& policies development for solar power potential in Pakistan.

Keywords - tariff; generation facility; renewable energy; sustainable; subsidize; irradiation; solar isolation; policy; transmission charges.

\section{INTRODUCTION}

\section{A. Literature Review.}

\section{- Potential of Solar Energy in Pakistan}

Pakistan, because of its geographical location has a huge potential of solar energy. The southern regions of Punjab, most of the part of Sindh \& Baluchistan, southern areas of Khyber Pakhtunkhwa are blessed areas for solar power or energy. This can be estimated from the solar map of Pakistan.

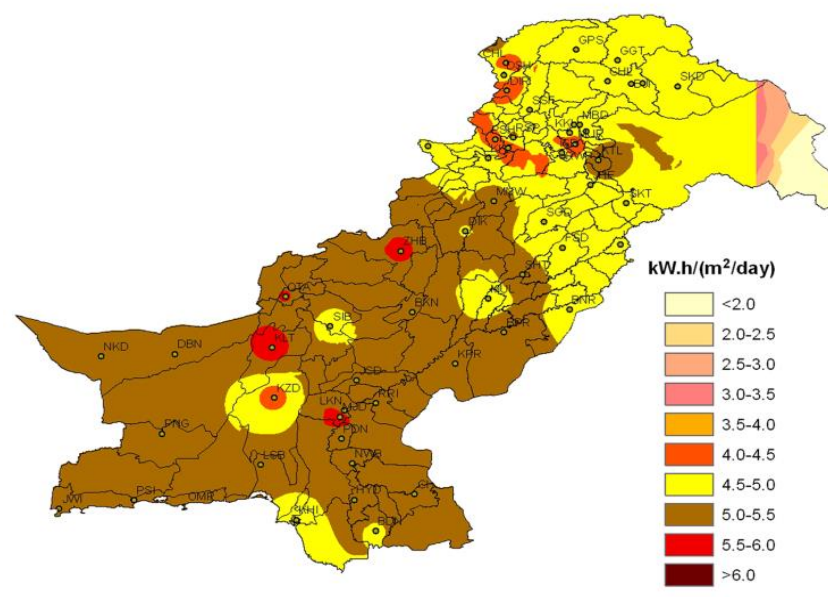

Figure 1: Solar Irradiation Map of Pakistan

Solar irradiations per year was measured \& schemed in whole of Pakistan \& outcomes were discussed on province \& region bases. In the regions of AJK \& Northern areas of 
Pakistan, lower limit of solar irradiations was observed to be $92.38 \mathrm{~W} / \mathrm{m} 2$ at Gupis region in the month of December \& lower limit of $339.25 \mathrm{~W} / \mathrm{m} 2$ in the month of June in the city of Gillgit. Solar irradiation value greater than $150 \mathrm{~W} / \mathrm{m} 2$ had been observed in different region of AJK from the month of Feb to the end of October whereas higher than $200 \mathrm{~W} / \mathrm{m} 2$ had been witnessed throughout the Northern areas \& the regions of AJK during the month of April to the end of September. In these areas, monthly mean or average solar irradiations remained $107.1 \mathrm{~W} / \mathrm{m} 2$ to 297.0W/m2 throughout the year [1].

Whereas in Khyber Pakhtunkhwa lowest incoming solar irradiation of $76.49 \mathrm{~W} / \mathrm{m}^{2}$ had been calculated at a station at Cheratt during the month of December \& highest solar irradiation of $319.33 \mathrm{~W} / \mathrm{m}^{2}$ at Risalpur in June. Solar irradiation was calculated to be greater than $150 \mathrm{~W} / \mathrm{m}^{2}$ from the month of March to the end of October in Khyber Pakhtunkhwa excluding for south regions, where the duration prolongs from Feb to Nov [2].

In KPK monthly average solar irradiations were found to be changing from $113.91 \mathrm{~W} / \mathrm{m}^{2}$ minimum to $295.75 \mathrm{~W} / \mathrm{m}^{2}$ maximum. It had also been witnessed many region in the south of Khyber Pakhtunkhwa has practical potential for solar thermal $\&$ photovoltaic power.

Punjab has a minimum of $96.11 \mathrm{~W} / \mathrm{m}^{2}$ solar irradiations, determined in the month of Dec in most of the zones of northeastern region where the factor of humidity is considerably high \& highest value of solar irradiation of $315.14 \mathrm{~W} / \mathrm{m}^{2}$ in southern Punjab in the month of May. Solar irradiation higher than $150 \mathrm{~W} / \mathrm{m}^{2}$, had been observed from Feb to Nov in the upper regions of Punjab excluding Muree the other hand lower southern parts of Punjab have high potential for both photovoltaic \& solar thermal applications. irradiation higher than $200 \mathrm{~W} / \mathrm{m}^{2}$ has been found to be consistent in many of the upper regions of the province during the month of March to the end of Sep for example in Mianwaali, Sialkot, Faisal-abad, \& many other regions in south regions of Punjab. On average monthly solar irradiation was found to be in between the range of $138.73 \mathrm{~W} / \mathrm{m}^{2}$ to $286.81 \mathrm{~W} / \mathrm{m}^{2}$ during the year [3].

In Baluchistan, lowest solar irradiation of $135.73 \mathrm{~W} / \mathrm{m}^{2}$ had been witnessed in the month of Dec at Jivani region \& highest solar irradiance of $329.05 \mathrm{~W} / \mathrm{m}^{2}$ has been calculated at Queta in the month of June. Solar irradiation higher than $152 \mathrm{~W} / \mathrm{m}^{2}$ was also calculated throughout the year with the exception of a few regions in north \& south western parts of Baluchistan, where this condition is persistent only from Feb. to Nov. Solar irradiation higher than $200 \mathrm{~W} / \mathrm{m}^{2}$ had also been observed from Mar to Oct. It has been recorded that monthly average solar irradiations varied between a minimum value of $153.61 \mathrm{~W} / \mathrm{m}^{2}$ to a maximum value of $281.94 \mathrm{~W} / \mathrm{m}^{2}$ throughout the year. [3]

Like Baluchistan, it has been observed that Sindh also has a lot of potential in solar thermal \& photovoltaic. It has been observed that solar irradiations persisted lowest $145.29 \mathrm{~W} / \mathrm{m}^{2}$ in Dec in the coastline areas \& highest value of $333.27 \mathrm{~W} / \mathrm{m} 2$ has been observed in central regions of Sindh throughout June. Solar irradiation value higher than $150 \mathrm{~W} / \mathrm{m}^{2}$ had been estimated in Sindh, exclusive of Rohrri, where irradiation was observed to be lower than $150 \mathrm{~W} / \mathrm{m}^{2}$ in Dec. The irradiation higher than
$200 \mathrm{~W} / \mathrm{m}^{2}$ had been estimated from Feb to Oct in the province except for the northern, western \& coastal regions of the province. Monthly average irradiation calculated was found to be between $164.44 \mathrm{~W} / \mathrm{m}^{2}$ to $298.97 \mathrm{~W} / \mathrm{m}^{2}$ during the year. [4]

Annual solar irradiation higher than $200 \mathrm{~W} / \mathrm{m}^{2}$ had been estimated in of the regions in the country except for some of the shoreline \& northerly areas. During summer season, the interval of the day stretches from 12-hour to 14 -hour \& in winter season 8-hour to 10-hour in Pakistan. Normally, 10-hour to 12-hour average interval of the day have been observed in Pakistan throughout the year. Solar irradiation is observed to be ranging from $1500 \mathrm{~W} / \mathrm{m}^{2} /$ day to $2750 \mathrm{~W} / \mathrm{m}^{2} /$ day [5].

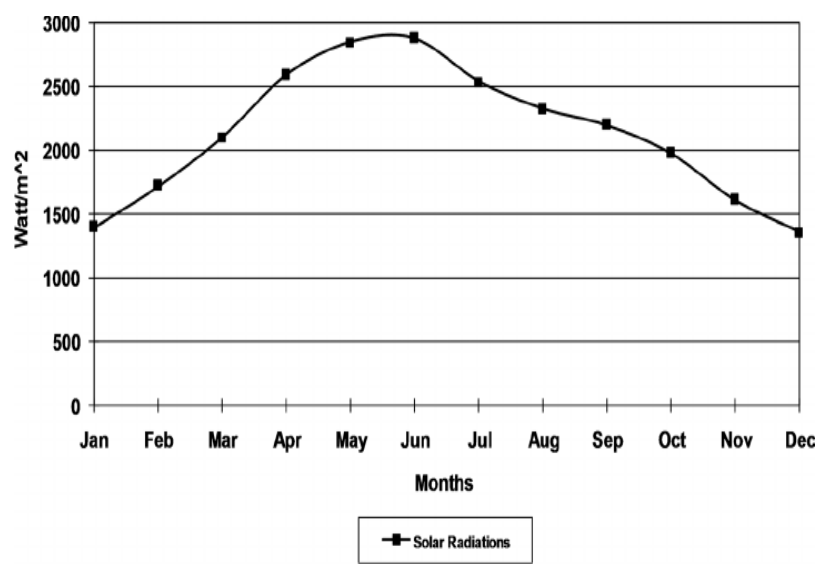

Figure 2: Solar Irradiations throughout the Year in Pakistan follow.

Briefly, solar energy potential in Pakistan is summarized as

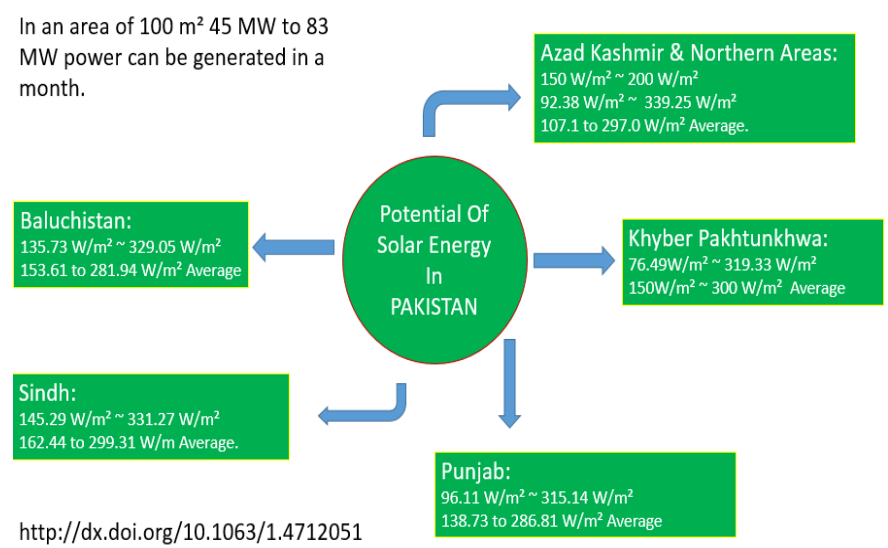

Figure 3: Solar Energy Potential in $\mathrm{W} / \mathrm{m}^{2}$ in all the provinces of Pakistan

\section{- Current Status. Of. Solar. Energy In. Pakistan}

The technological applications of Photovoltaic \& solar thermal for various purposes has been found to be very much limited as compare to the available potential of the energy from sun. Research has been carried out during the last few years to find out ways to fully utilize the full potential

On a smaller scale solar energy potential has been utilized for the last four to five decades. First ever solar panels in Pakistan were installed by Pakistan Telecommunication 
Company Limited outside Karachi \& then this technology was used by SNGPL for controlling \& reporting purpose. Currently SNGPL is one of the best utilizer of solar energy in Pakistan. A large number of different departments are paying attention towards the utilization of solar energy for electricity generation $\&$ thermal power applications.

The heat energy from the sun \& its irradiation can be used very much advantageously for the development of many technological applications such as cooking, drying, desalination \& energy generation. Such sort of technologies had been found to be of low cost, highly adaptable, commercially \& industrially more feasible \& economically efficient. A brief description of such applications in different areas in Pakistan is provided as below.

Using solar energy for heating of water is a solar thermal technology considered to be pretty established, but the utilization of this energy in our ccountry has been quoted to be quite limited for now, this is because of the market incompetency of such tools as they are pretty much expensive than the existing water heating systems \& other combustion applications. Many of the private $\&$ public sector organizations are working for the development of solar thermal techs especially in the extreme weather conditions, in the northern regions of the country where the energy sources are limited \& people use wood for burning \& heating purposes. Such applications are very much useful in areas where wood is found to be very much scarce. Many of the industries in different areas of Pakistan are using heat from the sun for preheating of water. Many of the leather industries has recently installed solar power heaters including Siddique Leather Works Lahore, Panjab.

Major Solar. Power generation is described as follow.

\section{Quaid-e-Azam Solar Park}

- Location: Bahawalpur

- Status: 100MW Completed

- $\quad$ Site Area: 6500 Acres

- Annual Net Output: 1530GWh

- Sanjwal Power Plant

- Location: POF Sanjwal

- $\quad$ Status: 5MW Completed

- $\quad$ Annual Net Output: 7.408GWh

- $\quad$ Site Area: 23 Acre

3 to5, 50MW Solar Power Plants are under construction in different districts of Southern Punjab. LOI has been issued for 5 to $10,50 \mathrm{MW}$ Power Projects.

50MW Project is also under construction in Gharo, Sindh. Many more solar power projects has been issued LOI in Sindh \& Baluchistan.

Solar cooking is also one of the most important renewable energy technology. In Pakistan's scenario, a large number of public \& private sectors had been working in the past $\&$ are working in the current times for the development \& implementations of more economical \& energy efficient designs for cooking purposes. Different type of solar cookers had been designed \& prepared for the last few years in both of the box \& concentrated type solar cooking systems.

A large number of solar cookers had also been distributed by different NGO's at Afghan refugee camps in Pakistan \& also at different regions of Khyber Pakhtunkhua, Baluchistan Sind \& Punjab. Regular training programs \& workshops are being arranged for the development of that technology, its use \& maintenance by Pakistan Council for Renewable Energy Technology [5]. According to a survey carried out in 2012, more than two thousand solar cookers are being used in different regions of Pakistan, whereas china uses more than sixty thousand solar cookers in the similar regions \& India uses more than fourteen thousand solar cookers in similar regions [7]. It is the need of the country to promote solar cooker use in different areas in order to decrease the utilization of treasurable woodland wealth as a fuel.

Energy from the sun had also been used effectively \& profitably for drying vegetables, fruits \& other agricultural products with the help of solar drying units. Solar dryers are more economical \& cost effective as compare to the conventional dryers \& methods, where the consumption of fuel $\&$ electricity pretty much higher. The northern areas of Pakistan such as Baltistan \& Swat areas are very rich for apricot $\&$ other fruits agriculture, unfortunately due to the lack of proper infrastructure $\&$ frying mechanism a huge amount of foodstuff is wasted. Solar dryers development in these regions my certainly save a huge amount of vegetable \& fruit stuff. Solar dryers had been installed in different regions of Punjab \& Khyber Pakhtunkhua by different NGO's \& private sectors. [7]

Solar energy is also used for converting saline water of the sea into drinkable water, the process is called solar desalination. This is the most affordable, economical \& efficient method used for desalination. Two desalination plants comprising of 250 stills with the desalination capacity of six thousand gallons of sea water had been installed in Gawadar, Baluchistan Province. The project at Gawadar has been very successful \& helpful in bringing about change in the life style of the locals [7].

Current Status of Solar Energy in Pakistan can be summarized as follow. 


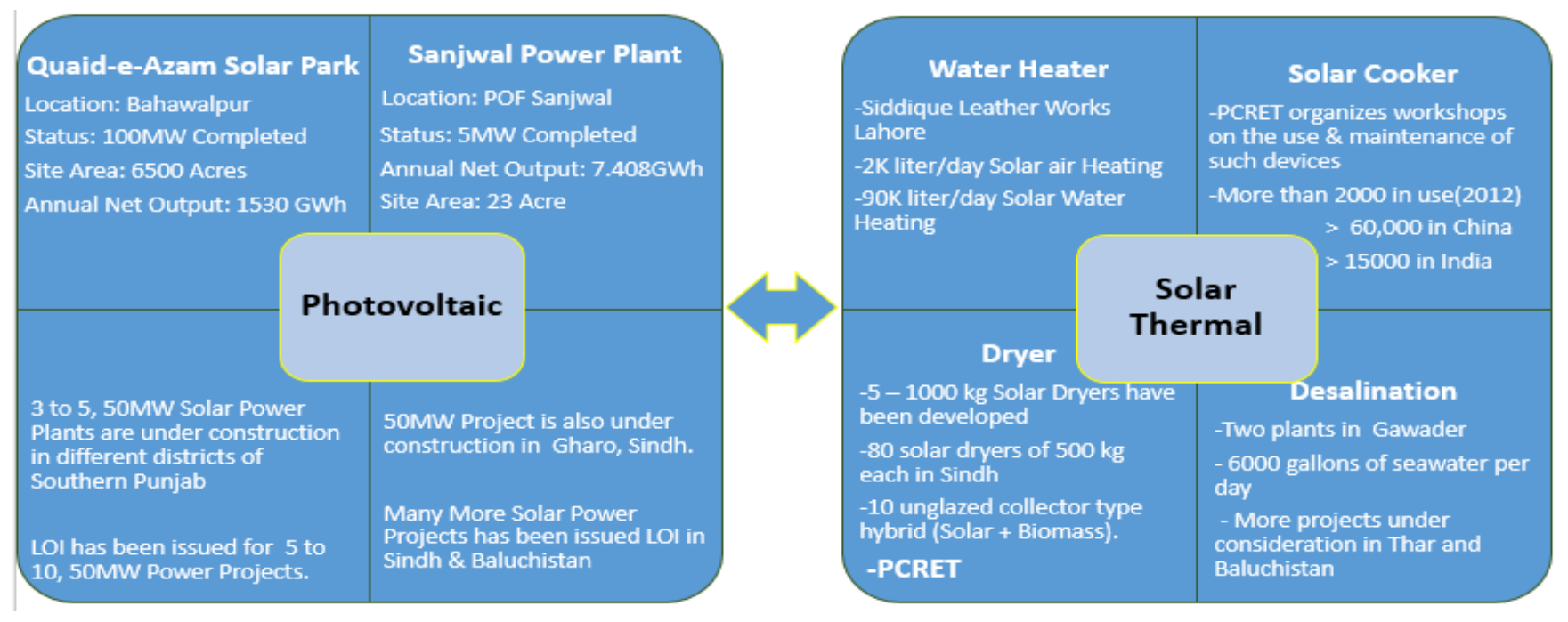

Figure 4: Photovoltaic Verses Solar Thermal Technologies in Pakistan

- Departments concerned with renewable energy

SERC (Solar Energy Research Centre) is a mono-functional part of PCSIR (Pakistan Council for scientific \& industrial research) which is situated in the Hyderabad Punjab \& is working under the Ministry of Science \& Technology Pakistan [8]. Main focus of this organization on research \& development in solar energy technology \& provision of tactics, methods \& implementation procedures for the development of solar energy in an effective \& efficient manner. Mostly research in SERC is carried out in the scope of solar heating technologies, counting generation of electricity using solar heat energy, solar water purification or desalination, solar water warming \& air conditioning etc.

NCAE, (National Commission for Alternate Energy) was to be developed for working to familiarize \& support for the encouragement of numerous solar energy technologies within the country. For the development of solar energy technologies, 2002 was witnessed to be the year of solar energy technology by GOP [9]. Dawn on twenty fourth of Oct 2004 described that NCAE \& IRET (Institute of Renewable Energy Technology) are going to be established in the near future [10]. Because of politically developed issues \& organizational postponements, these organizations had not been made functional by GOP.

NIST abbreviated for National Institute of Silicon Technology is an organization that has been established in 1981, was dedicated to investigation, improvement \& promotion of solar energy technologies, its importance \& need in general \& applied photovoltaic applications in particular in Pakistan. National Institute of Silicon Technology mainly concentrated mono-crystalline solar cell technologies (Applied Photovoltaic).

NIST provided facilities to develop silicon mono-crystals saw ingots into wafer $\&$ then process the wafers to manufacture solar cells, covering or laminating photo-voltaic modules \& attain an enhanced coordination of activities, actions \& to eradicate replication \& duplication of research work. PCRET has its head office in Islamabad.
There are 4 different offices in different regions of the 4 provincial capitals of Pakistan that is in Peshawar, Karachi, Lahore \& Quetta. PCRET has been given with the obligation of coordinating exploration \& implementation steps \& undertakings on sustainable \& renewable energy knowledge \& technologies in Pakistan, particularly in micro hydro biomass, biogas \& energy redeemable techs, solar water heating, solar drying, solar cooking \& many other solar energy prospective projects [11].

$A E D B$ abbreviated as Alternate Energy Development Board developed in the year 2003 to promote, expedite \& encourage the improvement \& development in sustainable, renewable \& alternate energy technologies in Pakistan. Its head office is located in Islamabad \& its administrative control is under the W\&P Ministry since 2006 [12].

PPIB abbreviated as Private Power Infrastructure Board was developed in 1994 when 1994 power policy was proposed, to facilitate the investors with one "window operation" \& promote public \& private investment in power sector by providing them with different sort of incentives. This was then made a statutory organizational body in 2012 .

PPC,s abbreviated as Private Power Cell, established in 1996, initially dealt with small or hydropower in different regions of Pakistan, where there is high hydro power potential, later on facilitated private sector participation for hydel power generation in AJK. It also deals with solar power generation on a smaller scale.

Pakhtunkhwa Energy Development Organization (PEDO), established in 1986 for the promotion \& encouragement of small hydro power development in the country as Small Hydropower Development Organization (SHDO), later on named as Sarhad Hydropower Development Organization (SHYDO) in 1993. In 2013 NWFP was renamed as Khyber Pakhtunkhwa as a result, name of the organization was also changed from SHYDO to PHYDO. From 2014 the organization was renamed as PEDO \& was made responsible to deal with the development, encouragement \& promotion renewable energy in Khyber 
Pakhtunkhwa. Different renewable power projects has been installed in different regions of KPK \& many are in pipeline.

\section{B. Pakistan Renewable Energy Policies (Solar Energy Prospective).}

Islamic Republic of Pakistan started working on Renewable Energy development in 1980s because of the huge electricity shortage within the country. In 1985 GOP proposed a private policy (a scheme) to introduce photovoltaic \& solar thermal in particular \& sustainable cum renewable energy in general. From the era of 1983 to 1988 planed a financing strategy to invest about 14 million rupees for research in solar \& biogas.

New energy \& power policies were proposed for electricity generation in of 1994, 1998, \& 2002. The 2002 Power Policy encourages private \& public sector investment for the improvement \& implementation of domestic fuel based power plants in Pakistan. Main purpose of the 2002 strategy stayed to generate $5^{*} 10^{2}$ megawatt of electricity by using sustainable or renewable sources of energy except for hydro power resource till the end of $2015 \&$ about $10 * 10^{2}$ megawatt by the end of year 2020. Even though large number of energy guidelines or strategies were presented for power \& energy generation from 1985 - 2002 that in fact concentrated on the need of exploiting renewable \& sustainable energy means, not a single policy gave an established \& spotless configuration towards the accomplishments solar \& other renewable energy related projects [13].

- 2006 Energy Strategy renewable energy development \& Promotion. (Solar Energy Prospective)

In the beginning of 2006 a policy was presented by $\boldsymbol{A E D B}$ (Alternate Energy Development Board) for the purpose of electricity generation known as "The Power Policy for the development of Renewable Energy". It is the first policy that was presented morally in order to develop, promote \& encourage renewable energy engineering projects in public \& private sectors. The goal behind this policy was to deliver \& assist the growing energy demand of the county by $10 \%$ by the end of 2015.

The 2006 policy solely emphasizes current of air or wind energy, solar \& micro hydro power schemes [14]. Objectives of the policy had been argued as under:

Improving the deployment \& utilization procedures of RE technologies in order to raise the power $\&$ power supply mix \& to ensure smooth supply of energy throughout Pakistan.

$>$ Encourage, assist \& back the investment from public \& private sectors in Renewable Energy Technologies via providing admirable incentive, support \& by embracing wideranging marketplace approach for RETs.

Develop robust procedures in order to fasten up the investment \& asset approach, analytically \& methodically support for the increase in number of a native Renewable Energy Technology Engineering facility. Such facilities pull down the cost \& also creates services \& cultivates technical \& managerial abilities at local level.

Proceed with strong \& effective processes, in order to raise per head power usage \& develop societal prosperity, particularly in faraway \& undeveloped regions where, dearth could be overtaken \& dependency biomass could be reduced. This will supports environmental protection \& provide awareness. The Renewable Energy Policy strategize to meet the defined traits via different initiatives. Substantial features Renewable Energy Policy are in detailed as under.

According to the policy, Private Sector Venture capitalists are heartened to set forth applications in the following three classifications.

1) IPPs Projects (Independent Power Producers)

Mostly for selling whole of the generation

2) Captive PPs. For self-use \& selling purpose

3) IGPPs: Isolated grid power projects

For micro-scale unconnected schemes.

Intended for the projects which are not IPPs, LOI, LOS \& IA by GOP are no more necessary.

Power Producers can bargain surplus power produced to the grid at one point \& obtain electrical energy, according to need, at some other point using net meter, the process is called net metering \& billing.

The Power Producing companies \& firms are allowed to inject electrical energy to the grid \& can acquire same amount of electricity at any other location by paying transmission charges.

Renewable Energy Technology tools \& devices had been freed from sale, custom $\&$ income taxes.

$>$ Independent Power Producers are allowed to acquire carbon credits.

$>$ Security of IPPs is ensured against the unpredictability of resources such as water discharge \& wind speed \& solar irradiation. Power purchasing station or utility will be responsible endure the threat or hazard.

Energy or power produced by Independent Power Producers is going to be purchased, entirely by Energy Supply Cos.

The Renewable Energy Policy has developed a small amount of passion for the expansion \& development of clean energy projects for electricity generation on major scale since its proposition in 2006 however the growth in renewable energy sector has been very slow \& small number of projects such as 50 megawatt wind energy projects at Kharo \& phase one of 100 megawatt Quaid-E-Azam Solar-Park has been completed [15]

2006 Renewable Energy Policy had certainly great aspects to boost up the development of Renewable Energy Technology but the steps taken by GOP since 2006 are not much admirable \& sufficient to develop momentously, the Renewable Energy sector of the country. This reflects the inability of RE Policy to deal with the most important matters \& issues. Moreover there are challenges related to Renewable Energy Scheme that needs to handle with care for the best interest of the sector. 


\section{Solar Energy Policy Of Peoples Republic of China}

Government of China planned for medium term \& long term policy to endure the development \& promotion of clean in Peoples Republic of china in the beginning of 2007, aiming for the utilization \& usage of energy from clean means to be raised by about $15 \%$ by the end of 2020. 2007 scheme was developed to empower China in developing of Renewable Energy Technologies, determine \& resolving nationwide \& province wise energy strategies. Targets of that scheme, were as follow.

- Targeting national energy demand, it provided additional active guidelines \& regulations for planning \& strategy at provincial level.

- Scheming highly in effect encouragement methodology.

- Boosting up the steadfastness \& sustainability of clean \& sustainable energy policies \& projects [16].

Briefly, REP (Renewable Energy Policy) of china is divided into 3 levels or categories that is $1^{\text {st }}$ level, $2^{\text {nd }}$ level $\& 3^{\text {rd }}$ level policies. $1^{\text {st }}$ level policy defines guidelines, methodologies $\&$ strategies in order to develop clean \& renewable energy to benefit society in a sophisticated manner. The second policy defines the goals \& objectives to empower the rural areas of China \& promote clean \& sustainable energy techs. At the end there comes the $3^{\text {rd }}$ level policies to define, inducements \& procedures for management of the schemes [17].

In 2006 Peoples Republic of China proposed a law called "Renewable Energy Law," which was amended in 2009 \& is maintained by two resources or funds. The former resource is consumers of electrical energy who pay in the name of "RE Surcharge" by an amount of 0.7 to 0.8 cents per kwh, \& RMB twenty to twenty five billion Yuan is expected collection at the end to each year $\&$ the second resource is Special Renewable Energy Fund, under the supremacy \& control Ministry of Finance. Special Renewable Energy Fund provides about ten to twenty Yuan at the end of the year.

Considering the geographical location of China, it is situated, 41.2 - 531.10 latitude North \& 731.00 - 3151.0 longitudes East in East Asia, spreading in wide spread in an area of about 9.6 million $\mathrm{km}^{2}$. Annually the solar irradiation of the country ranges from 3365 to $8405 \mathrm{MJ} / \mathrm{m}$.

Government of China given focus on provinces receiving highest solar radiations like Xinjiang, Ningxia \& some parts of Mongolia located in the west. Whereas, the western regions of the china is facing with problems such as connection with the grid, transmission \& distribution systems of electricity, hence government of China presented Different feed in tariff guidelines \& policies to develop mega scale systems throughout the country in 4 different regions across the country. The suggested FIT causing in decrease of the current feed in tariff of about 1.0 RMD per KWh up to $25 \%$ in different areas. The program or scheme has also calculated the limit of solar irradiation \& also will ensure that $8.01 \%$ of IRR could be attained in the above mentioned 4 locations [18].
According to 2013 statistics, $83.30 \%$ \& $43.01 \%$ rates of the system recorded to be dropped down in photovoltaic installations, from 2007 to 2013. In 2013 for RMD 10 to 12 Yuan/W a simple grid connected photovoltaic system had been installed. The rates of solar modules had been dropped from 36 Yuan/W to $4.5 \mathrm{Yuan} / \mathrm{W}$ in that tenure. Gross generation capabilities of top 10 solar photovoltaic manufacturing companies in Peoples Republic of China, calculated to be 16.9 $\mathrm{GW}$, whereas the yearly yield was calculated to be 13.01 gigawatt in the year 2013. The gross supplied module manufactured $\&$ fabricated in Peoples Republic of China was estimated to be $23 \mathrm{GW}$ in 2013 , which represents about $9.49 \%$ rise compared to 2011 , comprising of $61.80 \%$ contribution of the overall global manufacturing. According to 2012 statistics, total output worth of the Photovoltaic industry was estimated to be RMD thirty billion Yuan.

In 2012 Peoples Republic of China was the most prominent part of the globe in solar cell manufacturing \& yield among the topmost PV cells engineering corporations sharing about 12 GW in the year 2012 [19]. According to a research carried out in 2012, China shared more than 50\% of the world's total installed capacity. Even with that there had always been some hindrances for low level solar PV engineering businesses because of the commercial \& economic predicament in the country [20]. The government of China announced a separate policy or strategy for attracting the local or home solar cells manufacturers for the grid networks nationwide. There is an organization governing the grid connections called, SGC (State Grid Corporation) has been anticipated to allow native firms at urban areas to mount solar system of equal to or greater than $10,000 \mathrm{~kW}$, thus encouraging the companies \& manufacturers.

An organization named as NEA (National Energy Administration) witnessed that the installed capacity of solar PV is going to reach ten giga-watt by the end of 2015 \& $50 \mathrm{GW}$ by the end of 2020. The government of China, depending upon the policy expects to minimize the $\mathrm{CO} 2$ emanation by less than $16.98 \%$ \& energy utilization by less than $16.01 \%$.

Under that strategy, total investment was expected to reach about $\$ 803$ billion which was then allocated as $\$ 415.9$ Billion for energy generation sector \& an amount of $\$ 386$ billion was set for construction of grid \& transmission system. BRIC (group of countries that is Brazil, Russia, India \& China) countries have identified a subsidy of 0.42 Yuan for every kilowatt-hour of electricity generation through standalone systems \& facilities [21].Golden sun program had been initiated by MHURD (Ministry of Housing \& Urban Rural Development), MF (Ministry of Finance) \& NEA (National Energy Academy) in June 2009. Purpose of that program was the implementation of the solar power projects, of both the nature, that is off grid \& on grid systems. Government of 


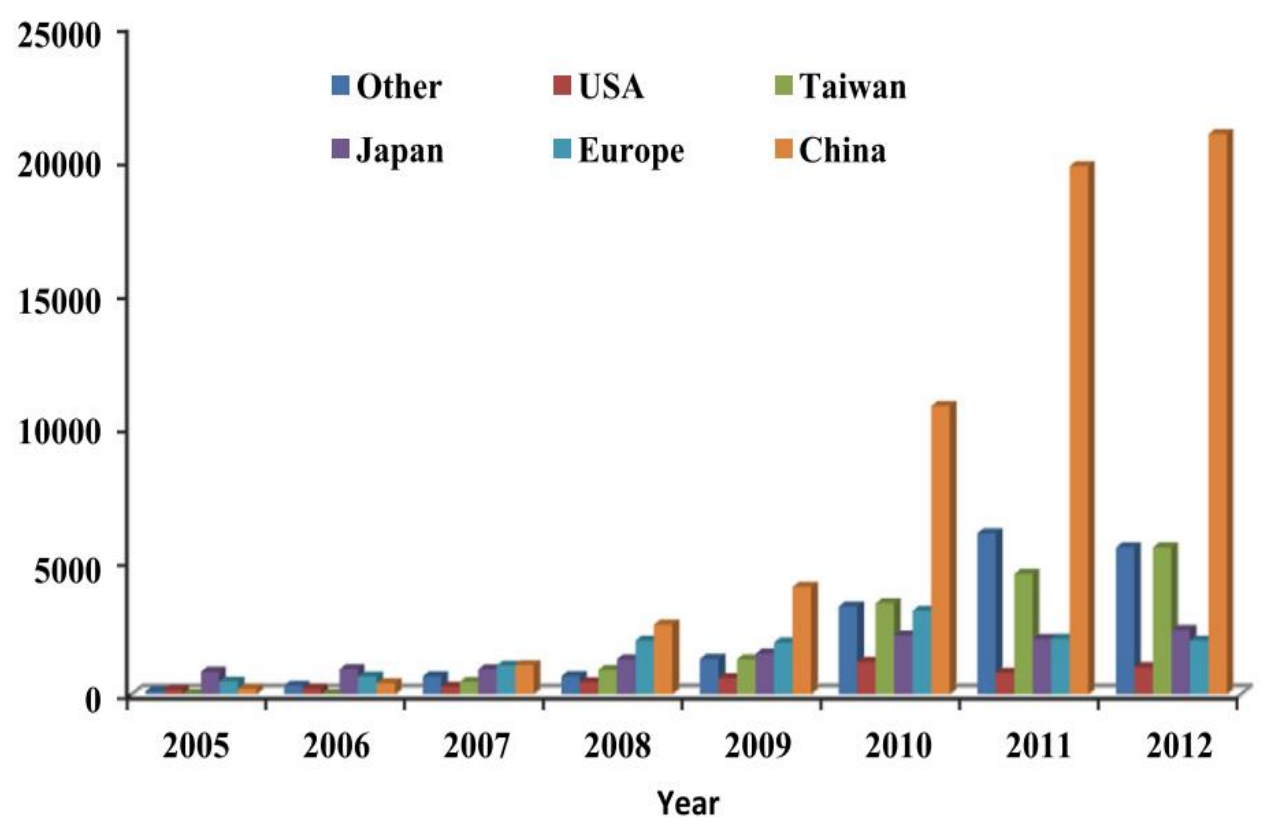

Figure 5: Worldwide Solar Power Generation till 2012

Peoples Republic of China has also provided a great support to subsidize $50-60 \%$ of the investment budgets. Nevertheless, this incentive was not sustained the generation of high quality power since financial challenge was created during operation \& maintenance of the system.

On Jan first, 2013 NEA (National Energy Administration) stated 12th plan of the country during 2011-2015 projections. Objective of the plan was that at the end of the year 2015, gross power production or generation was expected to close or equal to 1475 Giga-watt, however for energy generations from solar power, an additional increase of $89 \%$ was expected. The power generation of the country projected steadily by the addition of 5.0GW, 10.0 GW, 21.0 GW \& $35 \mathrm{GW}$ from 2011 to 2015.

\section{Renewable Energy Policy of USA (Solar Energy Prospective)}

According to a research carried out in the years 2010, USA contributed about $11.00 \%$ of the entire electrical energy through clean power resources \& systems \& it has also been observed, there was an increase of $77 \%$ in solar energy on annual basis. According to a research paper carried out in 2011 USA became one of the foremost nation state among $G_{-2} 20$ nation states for investing \& funding of wealth in sustainable \& clean power division. USA in 2012 fell hard from G_20 renewable \& sustainable energy headship for every single year, by a speculation dropping by $37.0 \%$ to an amount of $\$ 35.60 \mathrm{~B}$ [21]. It was estimated that at the end of the year 2012, USA touched gross solar cell capacity, approximately by $7.2 \mathrm{GW}$. However later in 2012, USA supplemented recent cap of more than almost $84.01 \%$ of gross cap of the year 2011 with a projected value of $\$ 11$ billion. The 11 states of USA put in more than $50 \mathrm{MW}$ of solar power in photovoltaic only in the year 2012 .
Domestic market showed a significant rise different regions of the country specifically in Arizona, Hawaii, California, New York \& Massachusetts, because on average domestic solar PV system rates fell by almost $20 \%$ in 12 months from $\$ 6.160 / \mathrm{W}$ in 2011 to $\$ 5.400 / \mathrm{W}$ in 2012 . On another hand, non-resident divisions, including marketable, governmental, \& nonprofitmaking systems, were put in more than $1000 \mathrm{MW}$ in the year 2012 [22]. If the policy for renewable energy of USA is analyzed, it comes out that four significant standings assisted the growth in the year 2012, which are

(I) Resolution in trade clash: import of solar cells from Peoples Republic of China was allowed by the government to decline rates of solar panels.

(II) $\quad 3^{\text {rd }}$ Party Kept Domestic Systems (Solar): this policyencouraged \& helped investors or third party vendors in installing new capacity. It was estimated that solar marketplace will be going to uphold its thrust $\&$ develop as a marketplace of worth $\$ 5.7$ billion by the end of 2016 under the supervision of GTM.

(III) Utilization of Solar Energy on Mega-scale: in the end of 2012 eight major solar power projects were installed in different states, most of these projects installed under the DOE Loan Guarantee program. This tendency or trait was intended to keep continue for the next year that is 2013, for the installation of almost more than $12000 \mathrm{MW}$ of utility.

(IV) Current PV Manufacturing consolidation: in 2012 the solar PV manufacturers observed slight assistance from worldwide superfluity for instance manufacturer precincts remained down \& less-reasonable utilities were closed around the globe [23, 24].

The recovery mechanism called "Modified Accelerated Cost Recovery System" helped to continue growth of solar PV 
by ensuring more market confidence $\&$ certainty for financiers. According to the policy of USA for renewable energy \& existing Federal law, welfare investment can also be taken for solar energy development. Photovoltaic schemes also make the grade for a fast track connection procedure according to their policy, which eliminate the necessity for expensive \& prolong studies, \& increasing the amount of solar appliances two times.

The Third Party Sponsoring assisted most of the solar manufactories in United States solar market place for customers, in receiving of maximum benefits. For instance $80 \%$ of residential areas in Colorado, solar power plants were installed in the month of January in 2013 by $3^{\text {rd }}$ Party Sponsoring Scheme Model [25]. Many of the states in United States of America, encourage net-metering \& billing for domestic \& marketing consumers who own generating units of solar power, to feed surplus electricity into the grid. Local Solar Permitting a part of the policy, helped solar power companies, depending upon state, domestic government, category \& proportions of the systems. Authorizing procedure needed huge amount of time \& high cost, on domestic \& commercial level.

One of the most important part of the policy is "The Investment Tax Credit" (ITC) in United States solar energy marketplace. But this was a short-term part of the policy that was proposed in 2005 \& was valid up to the end of 2012. ITC decreased tax charge for personages or industries, buying succeeding solar energy technologies, boosting up the private investment \& urging more the growth of solar power \& energy technology.

1604 Capital Package permits manufacturers, have national allowance within the shadow of the ITC, permitting taxpayers to increase yield \& amount of already existing power levy enticements [26]. It has been noticed that the states with lower energy burdens, slight shine most often provide with more inducements states having higher electrical energy costs \& a huge amount of sunshine in order to build a momentous market, [27].

It has been noticed that the permitting process required a substantial amount of time \& money, both on the domestic \& commercial values dependent upon location, government, native administration, category \& magnitude of the solar PV installed.

According to a research paper carried out in 2012, on Oct 2013, twenty nine states of USA, many districts in \& Puerta Rico \& Columbia RPS (Renewable Portfolio Standard) had been established. Photovoltaic market place stresses by the facilities located in those states where .RPSs. are in their place, to tackle the augmented ultimatum from $17.0 \%$ of grid oriented demand in year 2010 to $31.05 \%$ in year 2011. It has been noticed that for five more years, state RPS was going to be the most important element for running the utility [28].

It was noticed that in 2012, the total mounted capability had been decreased from NAP (National Average Price) by $26.60 \%$ i-e from $\$ 4.10$ per watt to $\$ 3.01$ per watt \& also NWAS (National Weighted Average System) value was decreased by $15.90 \%$ that is from $\$ 3.58$ per watt to $\$ 3.01$ per watt.
The United States Department of Energy has set a target to lessen down the price of the solar photovoltaic systems approximately by $75 \%$ at the end of 2020 in three sectors of photovoltaic deployment that is domiciliary roof-top, marketable roof-top \& off course service scale earth steed solar PV installations [29]. National Renewable Energy Laboratory (NREL) in 2008 reported that, 22-27\% of domestic structures are appropriate for lay on an on-site solar photovoltaic module structure. CRP (Community Renewable Program) had been backing up the increasing growth rates of solar energy systems. According to a report by solar buzz, by 2015 US had to justify for $12.01 \%$ of worldwide photovoltaic market place up from $5.0 \%$ making US $3^{\text {rd }}$ major photovoltaic marketplace in the world [30].

The TAX Policy part of the renewable energy policy, solar prospective played part in creation of jobs related solar energy generation, transmission \& distribution \& also playing its part in spurring economic growth, ensuring United States effectiveness \& competitiveness across the world, dropping energy utilization bills for users \& commerce, \& decreasing pollution \& emission of toxic gases markets throughout America. SunRun released a report that an unvarying authorizing process for domestic level systems could have reduced charges by $\$ 1$ billion for the next 5 years from 2010 to 2015 [31].

An act called "Ten Million Solar Roof-tops Act 2012" presented by Senator Bozeman provided a chance to the native populations to take good advantage of the solar permits \& use them with maximum efficiency [32]. Most significant aspects of that act are defined as under

I. Encouraging regularization \& homogeneousness for natives authorizing necessities in solar photovoltaic through the commands

II. Dropping the solar structure setting up expenses allied with native authorizing, advancing native authorizing

III. Native government's contribution in roof-top, or any other platform via energy department.

Main objective of that Act was to mount PV modules at more than ten thousand, thousand belongings situated in United States of America at the end of year 2020 reducing the price of PV structures especially of the modules $\&$ inverter systems.

\section{CONCLUSIONS}

\section{A. Challenges \& hinderances in Pakistan RE Policy (Solar Energy Prospective)}

Significant characteristics of renewable energy policy specifically the solar energy portion, of Pakistan has been discussed so far, reflecting positive aspects $\&$ then the solar energy policies of China \& USA has been gone through. After studying the policies of the above mentioned countries verses Pakistan I have come to the conclusion that these policies did not provide any help to fuel significant development in the renewable area over-all \& photovoltaic and solar thermal energy area in particular in Pakistan. Certainly there had been found some factor reflecting the inability \& weaknesses of the 
policy that needed to be considered seriously. Some of these inabilities are described as under.

\section{- Lack of Competition with Conventional Energy Systems}

The modern renewable energy technology can't compete preexisting or conventional energy technology in case of Pakistan. That's the electricity generated from conventional sources is inexpensive $\&$ more reliable compared to the advanced clean power tools \& know-hows despite of toll exemption. A research carried out in 2015 states the solar energy technology would have been undeniably the leading source for economic growth of the country, it the bigger investment had not been needed [33]. Because of the unavailability of domestic manufacturing units, tools of Renewable Energy Technologies are needed to be trade in, which intern escalating the expenditures of renewable energy schemes [34]. Another significant reason to take under consideration is that fuel oil is considerably endowed \& electrical energy produced from thermal plants is being credited by the GOP at raised expense [38].

\section{- Lack of Market Oriented Policies}

Compared to the existing or conventional technologies renewable energy technologies are not that much market oriented \& also have low market penetration rate. This is because of competition between the new technology \& the existing one, absence of responsiveness in community \& high rates of clean energy technologies. Moreover crude oil monopoly is very hard to challenge [35]. Moreover there doesn't exist any marketing strategy for the advertisement of RETs.

There is a need of market oriented policies \& strategies to be proposed \& implemented in order to nurture the market value of Renewable Energy Technologies. Elsewise the existing technologies will supersede RETs.

\section{- Lack of financial planning \& Strategy.}

Additionally, in Islamic Republic of Pakistan, strategy for finance that's the investment \& sponsorships for renewable projects doesn't exist, especially considering the micro-level projects. The basic reason behind this issue is the lack of appropriate familiarity about Renewable Energy Technologies, $\&$ also there are bigger menaces responsible for huge losses of in huge investments \& sponsorships due to the unpredictability resources such as wind speed, water discharge \& solar irradiations. Financial assistance from both national \& provincial government is needed to overcome these sort of risks.

\section{- Unavailability of Infrastructure Policy}

One of the reason behind the delaying development of Renewable Energy Technologies is the nonexistence of established infrastructures \& substructures. Per capita energy consumption in the undeveloped regions of the county is much lower due to the unavailability of deliberate structures such as transmission lines. It is extremely difficult \& costly to construct the structures $\&$ provide electricity to such places.
Additional challenge related to infrastructure is that, Renewable Energy Technologies, in general are not centralized $\&$ isolated, however the present electricity generating units (thermal \& hydel) had premeditated to be centralized systems in nature. There is a huge difference between the infrastructural necessities of decentralized system \& of centralized systems thus, the conventional system cannot be made-to-order to upkeep Renewable Energy Technologies more skillfully \& efficiently.

Beforehand of the establishment of Alternate Energy Development Board (AEDB), none of the government directorial entity was put in charge to propose \& develop strategies \& guidelines associated with RETs. Before the development of Pakistan Council for Renewable Energy Technology (PCRET), there were numerous conflicting organizational institutions with pitiable \& self-conscious objectives, such as Pakistan Council for Alternate Technology (PCAT) \& National Institute of Silicon Technology (NIST), which were merged together later on to develop PCRET as the two entities failed to deliver individually. Absence of collaboration \& contribution among governmental institutions, administrations, departments \& establishment exists even today. AEDB \& PCRET are most significant government bodies that can speed up \& increase development in renewable energy sector of Islamic Republic of Pakistan, the purpose of AEDB is to scheme \& device strategies whereas purpose of PCRET is to advance \& encourage RETs. If we need to bring vigorous improvement in novelty \& technology, AEDB \& PCRET must toil together towards a single goal. Consequently joint information \& statistics partaking \& working together with a great spirit can be profitable \& can lead to a dominate $\&$ productive renewable energy division of Pakistan.

\section{- Lacking behind in Information \& Technology}

Lacking in technological information \& knowledge regarding renewable energy engineering is a major hindrance towards the development of RET projects. Technical data is not even available to verify the resources \& the feasibility for installing a RET project out there for instance, info related to water discharge, wind speed \& solar irradiation. Approachability of such statistics is a fundamental need for encouraging financier \& for the enhancement of scheme. Applied knowledge concerning to establish tech is comprehensively unapproachable because of result in subnormal source assessment to the data banks, \& lacking in ample information regarding correlated practical \& economic concerns. Moving towards the commercialization of renewable energy technologies it is necessary to develop keen knowledge about the technology.

\section{- Unavailability of Skilled Personals}

Skilled manpower is very much necessary for the installation, maintenance \& running of the stations related to renewable energy, more specifically the accomplishment of renewable energy completely depends on skilled manpower. In current scenario, almost comprehensive unavailability of training institutes and technically strong personal for setting up, contracting \& looking after of such schemes exists. There is also a need of research activities to be carried out by researchers 
\& skilled workforce in different universities \& institutions. \& also there is a need of training the localities, for the maintenance of power projects related to renewable energy engineering.

\section{- Organizational, lack of Corporation}

Different government institutions \& organizations lack mutual communication \& participation in various schemes which is a great obstacle in developing RET in Pakistan. There was not a single institute or organization to develop renewable energy policies before the setting up of AEDB. AEDB \& PCRET are governing bodies in the renewable sector of Islamic Republic of Pakistan. To bring about change \& development in renewable energy technologies the two bodies must work together \& share technical \& theoretical knowledge with the institutions concerned to renewable energy engineering

\section{- Lack of communal awareness \& validation}

In order to boost the development in renewable energy technologies the policy must take good care of difficulties in communication \& publicity of renewable energy technology. There is a need of social awareness about renewable energy technology, campaigns should be carried out to popularize \& familiarize RETs all over the country \& good use of telecommunication towards the development of RETs is very much necessary[48]. Practical understanding \& cognizance related to assigning \& sustaining the schemes related to renewable energy is also insufficient which in turn stopping civilizations from probing unconventional energy routes.

\section{- Feed-in tariffs}

To boost the electricity value up from renewable energy sources Feed-in tariffs (FITs) has been the best policy approach for different countries around the globe. The Feed-in-Tariffs is a tool that actually develops an excellent competition among electrical energy generating companies. Introduction of Feedin Tariffs may bring a great change in the social power sector of the country concerning the renewable energy power projects. The policy make sure the accommodation of clean energy producers at fixed tariff for specific span. Feed-in tariff rates are further decreased from time to for the promotion of innovations. Feed-in-Tariff scheme has been used in different countries with awesome results.

\section{- Lack of Public Sector Participation}

Obviously, to broaden your horizons about the facilities \& utilities of renewable energy technologies in the country growth of market is very important unavoidable factor. The utilization of Renewable Energy Technologies on government structures is one of the easiest methodology to increase the dissemination of RETs (Renewable Energy Technologies) swiftly \& efficiently in market. Australia \& Germany are the countries that have used such methodology on practical basis.

To increase the proficiency of Renewable Energy Technologies, government of Germany palpably boosted Renewable Energy Technologies by mounting PV modules on Public sector structures. \& also the government of Australia also installed photovoltaic \& solar thermal technologies comprehensively in Sydney Olympic Stadium.

\section{- Lack of Proper Framework for SE projects}

To bring about the improvement of renewable energy project across the country, access to RET utilities \& facilities must be essentially improved. Moreover access to the data related to different locations \& facilities \& technology is also mandatory. In order to accomplish the goal, a systematically durable \& robust data sharing configurations \& structures must quickly be constructed which must have characters like access towards attainment of correct \& accurate material for the improvement, development \& maintenance of renewable energy schemes. This data sharing configuration manager needs to hold relevant understanding gained through Installing, processing, Preservation \& maintenance of renewable energy project.

Concluding the above this paper conveys a demanding \& serious assessment of usefulness of REP (Renewable Energy Policy) of Pakistan. Foregoing RE (Renewable Energy) correlated studies, been taken a trivial method that is just relaying on availability of resources \& snubbing the bottom line of policy or scheme design. I did comparison of countries, developed in solar energy with Pakistan such as Peoples Republic of China \& United States of America on the basis of fruitful policy making. A momentary summary of the policy strengths such as net-metering, feed-in tariffs etc. has also been given a detail. It has been concluded that even the distribution of Renewable Energy for more than ten years cannot be substantiated as catalytic if we talk about innovative professional prospects \& shifting conformist energy mix of Pakistan. Societies can't be profited despite of extraordinary enterprises. It is also concluded that the PPA (Power Purchase Agreement) \& the FIT (Feed in Tariff) cannot toil to organized disposition of solar photovoltaic modules etc. The consequences suggest that the development of above mentioned policies, along with fortitude to electrical energy charges by spotting domestic perspective can be more beneficial rather enacting of the policy unaided. Whereas implementation of policies via different organizations \& governmental red ribbon examination garble a decent policy.

\section{REFERANCES}

[1] PMD (Pakistan Metrological Department), Islamabad, Pakistan www.pmd.gov.pk

[2] S. Adnan, A. H. Khan, S. Haider, and R. Mahmood, "Solar energy potential in Pakistan," Journal of Renewable and Sustainable Energy, vol. 4, no. 3, p. 032701, 2012.Muhammad Zaid Azam;

[3] "The Scope of Solar Energy in Pakistan" 15 March 2012

[4] Abdul Basit: "Solar Energy in Pakistan" 11th Sep, 2012

[5] Azmat Hayat Khan,1 Shahzada Adnan,1 Sajjad Haider,1 \& Rashed Mahmood2 "Solar Energy Potential in Pakistan" May 2012

[6] U. K. Mirza, M. Maroto-Valer, and N. Ahmad, "Status and outlook of solar energy use in Pakistan," Renewable and Sustainable Energy Reviews, vol. 7, no. 6, pp. 501-514, 2003.Nasir Ahmad ,Umar K. Mirza , M. Mercedes Maroto-Valer : "Status of solar energy use in Pakistan" 30 June 2003 pg\# 10-11

[7] AEDB (Alternate Energy Development Board), www.aedb.org.

[8] PPIB (Private Power Infrastructure Board) www.ppib.org.pk

[9] PEDO (Pakhtoonkhwa Energy Development Organization) www.pedo.kpk.org.pk

[10] "Role of feed in tarrif in developing countries, a toolkit for parlimentation" EEDN for Africa (AFREPREN); 2014 
[11] A. B. Awan and Z. A. Khan, "Recent progress in renewable energy Remedy of energy crisis in Pakistan," Renewable and Sustainable Energy Reviews, vol. 33, pp. 236-253, 2014.

[12] GoP. Policy for the development of Renewable Energy In Pakistan, 2006

[13] RETs and sustainable development in Islamabad: COMSATS: Islamabad, Pakistan; 2012

[14] Fang L, Honghua X, Sicheng W. IEA corporate program on photovoltaic Energy System. NSR photovoltaic generation in China; 2012.

[15] http://www.renewable-energy-technology.net/solar-energy-news/chinaintroduces-20-year-pv-subsidy-policy-boost-solar-power

[16] https://www.pewtrusts.org/en/projects/archived-projects/clean-energyproject

[17] https://www.greentechmedia.com/articles\%20/read/u.s.-solar-marketgrows-76-in-2012

[18] U.S. solar market insight report|2012 year in review| executive summary, GTM \& SEIA reports.

[19] https://www.seia.org/research-resources/us-solar-market-insight-2012year-review

[20] https://www.seia.org/\%20policy/finance-tax/third-party-financing

[21] https://www.seia.org/\%20policy/finance-tax

[22] https://www.seia.org/\%20policy/distributed-solar/rebates-incentives

[23] https://cleantechnica.com/2011/08/08/us-solar-pv-to-double-in-2011grow-47-a-year-to-2015/

[24] A. Goodrich, T. James, and M. Woodhouse, "Residential, Commercial, and Utility-Scale Photovoltaic (PV) System Prices in the United States: Current Drivers and Cost-Reduction Opportunities," 2012.

[25] https://www.seia.org/initiatives/local-solar-permitting

[26] Renewable Energy Policy Profiles, 2011

[27] http://tribune.com.pk/story/154420/countrywide-energyshortageaspepco-increases-loadshedding/S

[28] U. Zafar, T. U. Rashid, A. A. Khosa, M. S. Khalil, and M. Rashid, "An overview of implemented renewable energy policy of Pakistan," Renewable and Sustainable Energy Reviews, vol. 82, pp. 654 665, 2018. Awan KY, Rashid A. Overview of Pakistan's electricity crisis, generation-mix \& renewable energy scenarios. Int J Eng. Technol 2012; 1(4):321-34.

[29] 〈http://data.worldbank.org/country/pakistan〉

[30] A. Ford, "Using simulation for policy evaluation in the electric utility industry," Simulation, vol. 40, no. 3, pp. 85-92, 1983.

[31] Dyner I, Bunn D. Simulation platform to analyze market liberalization \& integrated power conservation policies, Columbia. System modelling for Energy Policy. NY, John Wiley \& Sons; 1997. p. 259-71

[32] T. Govindaraj, "Characterizing performance in socio-technical systems: A modeling framework in the domain of nuclear power," Omega, vol. 36 , no. 1, pp. 10-21, 2008.

[33] M. Javid and A. Qayyum, "Electricity consumption-GDP nexus in Pakistan: A structural time series analysis," Energy, vol. 64, pp. 811-817, 2014..

[34] Package incentives for private sector power generation in Pakistan. GoP; 1994

[35] Olaya Y, Dyner I. Modelling for policy assessment in the natural gas industry. J Oper Res Soc 2005;56(10):112231 